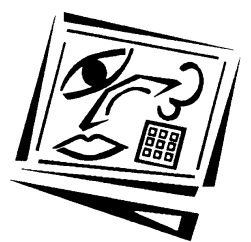

\title{
Assessing technology integration: Its validity and value for classroom practice and teacher accountability
}

\author{
Kathleen A. Bowes, Antonia D'Onofrio \\ Widener University, USA \\ Elaine S. Marker \\ Rowan University, USA
}

\begin{abstract}
This article questions whether popular approaches to the assessment of technology integration with classroom instruction are valid. The article explores Messick's (1993) conceptualisation of consequential validity, in an attempt to understand what validity must be evident when the integration of technology with classroom instruction is assessed. This article also compares and contrasts assessment tools and systems that are currently used, searching for evidence of valid assessment. Individually these tools sample a very limited collection of teacher knowledge and skill. Against a backdrop of rapidly expanding expectations and rapid change, the tests are probably unable to capture what teachers need to do, and more importantly what they actually are doing. The article concludes with recommendations to strengthen the validity of assessments of technology integration.
\end{abstract}

\section{Introduction}

Do teachers make valid self appraisals when they use surveys, questionnaires and checklists to assess their skill at integrating technology with classroom instruction? When administrators assess teacher competence at technology integration, do they make valid judgments about teacher skills and meaningful decisions about staff development? The answers to these questions depend upon the validity of assessment practices that teachers and administrators use.

This article questions whether popular approaches to the assessment of technology integration with classroom instruction are valid. The article explores Messick's (1993) conceptualisation of consequential validity in an attempt to understand how validity must be evident when the integration of technology with classroom instruction is assessed. This article also 
compares and contrasts assessment tools and systems that are currently used, searching for evidence of valid assessment. The article concludes with recommendations designed to strengthen the validity of assessments of technology integration.

Technology is integrated with instruction when it is used to further the achievement of curriculum goals and when it is deeply embedded in instructional processes associated with a curriculum (Recesso, 2004). Engaging students in online communities, social networking, web conferencing, and interactive problem solving are facilitated, not only by the presence of computers and software, but also by consciously redesigning the context of learning so that technology provides more opportunities for students to achieve goals of collaboration, communication and active learning (Leamnson, 2001). Technology integration can be demonstrated in various ways: through the use of the Internet for instruction; interactive activities that are web based; uses of web and other computer based projects that may be outcomes of student initiatives and student creativity; word processing; the incorporation of various media, such as digital photography, media players, audio, streaming video; and working with spreadsheets (Oliver \& Omari, 1999). Technology when effectively integrated with instruction can thus be argued to improve both the processes and outcomes of teaching and learning (Pope, Hare \& Howard, 2002).

\section{Content, construct and consequential validity: Three perspectives}

An essential purpose of assessment is to make decisions regarding competence - that of teachers, students, administrators, and the overall context of technology integration in a particular school, or a school district as a whole. Teacher accountability is based on assessment. Professional development decisions are also based on assessment. Even the approaches that will be used for professional development are assessment driven in many cases. For these and other decisions to be useful, meaningful and fair, validity should be a fundamental concern.

Tests are frequently evaluated by examining both their content validity, as well as by investigating the statistical correlations between a target test and related tests of the same or similar content (Cronbach, 1989; Fink, 1995; Goldstein \& Hersen, 1984; Kerlinger, 1979; Nunnally, 1978; Trochim, 2002; Wilson, 1992-1994). These activities are employed to establish construct validity. Content validity and construct validity are inter-related, but nonetheless distinct, aspects of the validity of test scores (Messick, 1993; Trochim, 2002). Messick $(1989,1983)$ connected the more technical aspects 
of content and construct validity to test relevance, and thus explored the question of whether decisions based upon test scores are meaningful and fair. In so doing, he proposed a third type of validity which he termed consequential validity.

\section{Content validity}

Content validity demonstrates the ability of a test or assessment procedure to tap into the knowledge and skill associated with an area of instruction (Fink, 1995; Trochim, 2002; Wilson, 1992-1994). At its most basic level, content validity refers to a match between a test and its item content, as well as the levels of skill found within the domain of knowledge targeted by a test (Moersch, 2002). How would content validity play a role in the assessment of technology integration with classroom instruction? Teachers are expected to employ technology, as well as to demonstrate their competence using behaviours that are extensive. They are judged in terms of how much they know about instructional technology, the skills they use, and how well they apply their knowledge and skills. Thus they must demonstrate a variety of abilities in a variety of contexts. They are also expected to engage students as willing partners in technology in the classroom. Teachers are expected to integrate productivity tools with instruction, and also integrate the Internet, email, the use of mobile devices, educational software and more. They are expected to create learning environments in which students are actively engaged, and where students demonstrate their own competence using technology.

In the 1980s students used kill and drill software. That was so because the software available to teachers was limited to the reinforcement of skills and knowledge learned. By the 1990s, productivity software became more available. Today software that nurtures the development of higher order thinking is widely used (McKenzie, 1994, 1998). In the early 1990s, digital media were not available in the schools. Teachers had to learn to use these tools, and that required them to add to the already considerable list of competencies that were expected. They needed to be able to create classroom applications that went beyond the entertainment value of these media and contributed to experiences that were cognitively rich. After 1994, digital communication (classroom applications of email and the World Wide Web) began to command attention as the next classroom revolution in technology integration. Today the Internet remains essential to classroom uses of technology, but delivery modes have shifted focus from the desktop and the computer lab to mobile devices and wireless technology (Johnson, 1998; Kinzer \& McKenna, 1999; Wepner \& Tao, 2002). Content validity, therefore, may be particularly difficult to establish for contemporary assessments, because, in practical terms, there is no way to predict what the universe of information about teacher competence might 
include 6 months, a year or 18 months beyond a particular time when benchmarking of teacher knowledge and skills may be needed.

\section{Construct validity}

Construct validity demonstrates that scores generated by assessment procedures are statistically correlated with independent measures of similar content and skill, and uncorrelated with material that is dissimilar in content and extraneous to the purposes and goals of assessment (Cattell, 1978; Cronbach, 1989; Gorsuch, 1983; Nunnally, 1978; Russ-Eft, 1980; Thompson \& Daniel, 1996).

Demonstrating construct validity is a complicated matter. Many statistical investigations of a single test are required. Such analyses would answer the question of whether any assessment procedure measures technology integration in ways that correspond to assessments made by established instruments. Anastasi and Urbino (1978) recommend that construct validity be explored through a series of testable hypotheses which, when answered, will help define the theoretical definition of ability or skill. Settling on a theoretical definition of technology integration is not easy in practice. One may find as did Robertson, Fluck and Loechel (2004) that field based studies of teachers can lead to definitions that stress the place of technology within a context of authentic pedagogy. They argue that technology integration may entail the support of varied learning processes: scaffolding and mediation of learning; inquiry processes; integration of knowledge occurring outside of school; greater collaboration; awareness of shared experiences; the creation of social networks; interactions in schools and classrooms that are more frequent and more varied. Another theoretical definition of technology integration may, conversely, focus on the extent to which specific skills are put into play in the classroom. Under this banner, technology is integrated when it supports access to information (email and the Internet); enhances the presentation of information (graphics, presentation software, audio and video applications); and improves upon information management (using productivity tools).

Messick has proposed that construct validity can and should be demonstrated using a variety of procedures, all of which attempt to show statistical correspondences between a targeted assessment procedure and related assessments of knowledge and skill. Statistical demonstrations of validity would include evidence of predictive validity, systemic validity, concurrent validity, and convergent versus divergent validity. As each type of statistical validity is combined with the others, an overall picture of a test's ability to assess the presence of a construct emerges. 
Construct validity in sum should be viewed as the outcome of continual and systematic efforts of test validation. Valid assessment of teacher competence in technology integration would similarly depend on step by step efforts to validate assessment tools. What do these steps look like? How are they demonstrated using assessments of technology integration? Investigations of predictive validity, systematic validity, and concurrent validity, convergent and divergent validity comprise the systematic evaluations that are needed to establish construct validity.

\section{Predictive validity}

Predictive validity depends on the ability of assessment tools to predict future performance (Cattell, 1978; Kerlinger, 1979; Nunnally, 1978; Trochim, 2002; Wilson, 1992-1994). Predictive validity is usually established through regression studies in which assessment information gathered at Time A is found to be positively correlated with scores (or other quantifiable information about knowledge and skill) gathered at a future Time B. How would the principle of predictive validity translate into school district assessments? The assessment used to measure teacher knowledge and skill would have to supply information that could be related statistically to future measures of teacher knowledge, attitudes, behaviours or other measures of teacher competence. From a purely practical vantage point, school district administrators would have to determine teachers' entry level competence in order to establish a baseline from which to make inferences about future growth and potential, if they wished their assessments to possess predictive validity. The school district administrators would then subsequently collect more information, using different and independent tools that purport to measure the growth of teacher competence. This process would employ a battery of behavioural inventories, self assessments completed by teachers and/or observational tools. Regression analyses would have to produce positive and statistically significant correlation between scores gathered at Time A with those gathered at Time B (Cook \& Campbell, 1979; Kerlinger, 1979). Because this kind of investigation has intrinsic value for professional development, studies of predictive validity have more than technical importance to the assessment of technology integration.

\section{Systematic validity}

Systematic validity is based upon the correlation of measures of the same or related constructs. In demonstrating systematic validity, tools that assess teacher competence should be different and their content should not overlap (Messick, 1993; Trochim 2002). Rather, each assessment should base measurement on different working definitions of what teacher competence ought to be like. For example, the implementation of a continuous, long range assessment protocol would employ several 
different measures of teacher competency and correlate scores measuring teacher outcomes.

\section{Concurrent validity}

Concurrent validity, a close cousin of systematic validity, demonstrates correlations among independent assessments of the same underlying dimensions of knowledge or skill (Wilson, 1992-1994; Messick, 1993). Assessment should be able to demonstrate that the performance of teachers who have been described as highly competent in technology integration using one assessment procedure, is consistently high on other measures of technology integration. Concurrent validity cannot be demonstrated unless an independent measure of technology integration already exists that has established its own reliability and statistical validity. Assessment would also have to demonstrate that the content of the assessment corresponds to what is happening in the real world of the classroom. Finally, score distributions describing lower to higher levels of competence should be correlated with independent and field tested assessments of teacher expertise. There are no studies of technology integration that establish the concurrent validity of any of the currently popular assessment tools.

\section{Convergent and divergent validity}

Convergent and divergent validity (mutually opposing correlational patterns) are explored with the ultimate goal of demonstrating both the similarity and dissimilarity of assessment information (Cattell, 1978; Cronbach, 1989; Gorsuch, 1983; Guttman, 1950; Linacre, 2000; Messick, 1993; Nunnally, 1978; Thompson \& Daniel, 1996). When similar measures of competence are positively correlated, and conversely, dissimilar measures are uncorrelated (significant coefficients cannot be discovered), then the patterns of convergence gained from positive correlation coefficients, and patterns of non-correlation, illustrate what an assessment measures and what it does not measure.

\section{Consequential validity}

Messick (1993) has argued that the validity of any test depends on whether test results lead to useful, meaningful and fair decisions, thereby making validity a consequence of testing and assessment, and thus he introduced the notion of consequential validity. When both content validity and construct validity are evident in a test or an assessment procedure, then "value implications" (p. 13) of a test can be demonstrated, because value in combination with construct validity is requisite for decisions that are useful, meaningful and fair. Messick thus understood validity to mean more than purely the technical soundness of assessment, extending the understanding of test validity to include the soundness of decisions made on the basis of test or assessment procedures. 
When assessments are used to make decisions about teachers, the assessment tools are very often of the 'one size fits all' variety. Although they may assess baseline proficiencies for groups that are important to know, they may also ignore unique abilities and interests of teachers who are rather gifted in terms of special talents, for example, an emphasis on applications of the Internet or wireless applications. Some teachers may indeed use less of one sort of technology and more of another; however the measures used to assess teacher competence may provide a distorted view of whether the teacher is integrating technology, or of that teacher's level of skills.

\section{The design and uses of current assessment strategies}

Moersch compared the psychometric characteristics of a variety of technology assessment tools $(1999,2002,2004)$. These assessment tools included: CTAP Online iAsessment and Technology Use Survey, EnGauge, SIE*TEC Technology Integration Profiler, and TAGLIT. He contrasted these instruments in terms of the following six design features: item analysis, feedback, multiple versions, standards alignment, prescriptive use, and customisation. Of the categories Moersch explored, only item analysis and standards alignment are distinguishable as psychometric test attributes. Item analysis relates test content to skills and outcomes; and standards alignment correlates text content to expected skill attainment and ideal outcomes of a technology curriculum (Ryan, 2003). Item content and skills alignment pertain to the content validity of technology integration assessment. Moersch (2002) also indirectly explored the broader concerns of consequential validity, that is, the value of an assessment tool for the purpose of making decisions. Thus Moersch linked choices of an assessment tool to the availability of feedback, multiple forms of a test, and the ability to customise assessment to the nature of staff development or training.

Although Moersch appears to have investigated content validity and to have identified a number of deficiencies that were characteristic of several popular instruments used today to assess technology integration, it was difficult to access this information in order to review it. It was not easy to establish a foundation for content validity because the content of the various tools in this study was often described so differently. For example, basic skills in the Mankato Scale and CTAP2 were referred to as 'digital age skills and processes' in enGauge. Frequently, test content was impossible to access. For example, in order to review the content of CTAP2, it was necessary to search California online reports about this tool to view sample content. Response formats were also very different. Some tools depended on the use of rubrics to scores responses; whereas others used rating scales to gather self reported responses. In some cases items are customised for 
specialised assessments and test items are drawn from larger banks of items known only to the test publishers.

Because of these difficulties, the authors used the following methods to conduct a more systematic comparison of the assessment tools and their content.

1. Table 1 is a synopsis of assessment tools that are currently used to assess technology integration in today's classrooms and schools. These were as follows: SEIR*TEC Progress Gauge, TAGLIT, enGauge, CTAP2 iAssessment, NCRTEC Learning with Technology Profile Tool, and the Mankato Scale. Assessment tools are compared based on the following attributes: Content, Purpose, Design and Development and Samples of Items.

2. Table 2 indexes the content of each tool to specific International Society for Technology in Education (ISTE) standards [http://www.iste.org/].These are standards for both the implementation and evaluation of technology integration and thus serve as reasonable benchmarks for examining technology assessment tools. Since ISTE Standards I through VII apply to classroom integration, this analysis indexed those standards only. Site's Standard VIII applies to leadership and vision for an entire educational unit. Therefore Standard VIII was not part of the investigation of assessment tools.

3. Figure 1 makes it possible to compare and contrast the pedagogical focus of each of the assessment tools.

A web address for each instrument has been reported when available in Table 1. Test content is often available as downloadable files or PDF files. Some of the assessment tools are interactive and online (TAGLIT, EnGauge and CTAP iAssessment). All but the Mankato Scale require logon identities to view test content. Only one, TAGLIT, allows for a guest account so that test content can be viewed. The content of each tool is unique. Some of these assessments may look at proficiency or competence; or they may look at the level of engagement or level of involvement. All are self assessments; however, they may employ rubrics or Likert type rating scales to gather information. Assessments may focus on teachers, on several district constituencies, or on district wide engagement and integration. Assessment purposes can vary widely. Technology integration assessments can monitor mentoring or efforts to foster mentoring over time (SEIR-TEC), or can be used to help school leaders gather information and plan (TAGLIT, EnGauge). CTAP iAssessment is used to monitor levels of teacher proficiency; and NCRTEC and the Mankato Scale help educators evaluate their strengths and weaknesses. Only the Mankato Scale indicates that the assessment content is aligned with National Educational Technology 
Standards (NETS) [http://cnets.iste.org/sitemap.html\#teachers]. These are attributes that contribute to understanding the validity and the intended uses of an assessment. However, statistical validity and consequential validity cannot be evaluated from the information that was gathered and presented in Table 1.

Table 1: Synopsis of technology assessment tools

\begin{tabular}{|c|c|c|c|}
\hline $\begin{array}{c}\text { Test name and } \\
\text { URL }\end{array}$ & Purpose & Content & $\begin{array}{c}\text { ISTE } \\
\text { Standards } \\
\text { addressed }\end{array}$ \\
\hline $\begin{array}{l}\text { SEIR }{ }^{*} \text { TEC - } \\
\text { Progress Gauge } \\
\text { www.seirtec.org }\end{array}$ & $\begin{array}{l}\text { Designed as a survey } \\
\text { of teacher instructio- } \\
\text { nal practice and tech- } \\
\text { nology integration } \\
\text { Intended as tool for } \\
\text { teacher self } \\
\text { improvement and } \\
\text { school improvement } \\
\text { Companion piece to } \\
\text { this survey is LoFTI } \\
\text { Observation Survey. }\end{array}$ & $\begin{array}{l}\text { Assesses level of technology } \\
\text { use in several areas: } \\
\text { student engagement; } \\
\text { environmental quality for } \\
\text { teacher engagement; } \\
\text { accessibility of appropriate } \\
\text { resources; organisational } \\
\text { support community } \\
\text { involvement }\end{array}$ & I, II, III, IV \\
\hline $\begin{array}{l}\text { TAGLIT - Taking a } \\
\text { Good Look at } \\
\text { Instructional } \\
\text { Technology } \\
\text { www.taglit.org }\end{array}$ & $\begin{array}{l}\text { Provides a profile of a } \\
\text { personal "perception } \\
\text { of technology use and } \\
\text { impact on schools". } \\
\text { This suite of tools for } \\
\text { assessment measures } \\
\text { changes resulting } \\
\text { from technology } \\
\text { initiatives. }\end{array}$ & $\begin{array}{l}\text { Organised so that teachers } \\
\text { can personally assess their } \\
\text { ability to integrate } \\
\text { technology. One section } \\
\text { consists of an open test area } \\
\text { where teachers respond to } \\
\text { curriculum, } \\
\text { hardware/software, and } \\
\text { professional development } \\
\text { Teachers also supply } \\
\text { information about } \\
\text { hardware, software, } \\
\text { electronic/ online } \\
\text { references, technical/ } \\
\text { instructional support and } \\
\text { their school's technology } \\
\text { plan. }\end{array}$ & $\begin{array}{l}\text { I, II, III, IV, } \\
\text { V,VI, VII }\end{array}$ \\
\hline $\begin{array}{l}\text { EnGauge } \\
\text { www.ncrel.org/ } \\
\text { engauge/ }\end{array}$ & $\begin{array}{l}\text { Intended to provide a } \\
\text { view of educator } \\
\text { proficiency in: } \\
\text { technology skills; } \\
\text { planning; } \\
\text { implementing; and } \\
\text { assessing technology } \\
\text { supported learning }\end{array}$ & $\begin{array}{l}\text { Intended for teacher use to } \\
\text { determine how effectively } \\
\text { they engage students in } \\
\text { learning through the use of } \\
\text { technology and how well } \\
\text { their technology resources } \\
\text { support their practice }\end{array}$ & II, VI, VII \\
\hline
\end{tabular}




\begin{tabular}{|c|c|c|c|}
\hline $\begin{array}{l}\text { CTAP2 } \\
\text { www.scusd.edu/ } \\
\text { education_techn } \\
\text { ology/CTAP_- } \\
\text { online_iassess } \\
\text { ment.htm }\end{array}$ & $\begin{array}{l}\text { Intended to evaluate } \\
\text { California school } \\
\text { districts applying for } \\
\text { the 'Enhancing } \\
\text { Education Through } \\
\text { Technology' using } \\
\text { online assessment } \\
\text { and reporting } \\
\text { Based on technology } \\
\text { proficiency and } \\
\text { district support for } \\
\text { technology learning }\end{array}$ & $\begin{array}{l}\text { An online self assessment } \\
\text { that examines } 9 \text { discreet } \\
\text { areas of technological } \\
\text { proficiency: general } \\
\text { knowledge of technology; } \\
\text { Internet, email, word } \\
\text { processing; publishing; } \\
\text { databases; spreadsheets; } \\
\text { and presentation skills } \\
\text { A rubric provides } \\
\text { evaluation of teacher } \\
\text { proficiency in each area. }\end{array}$ & I, III \\
\hline $\begin{array}{l}\text { Mankato Scale } \\
\text { www.doug- } \\
\text { johnson.com/ } \\
\text { dougwri/ } \\
\text { rubrics2002.html }\end{array}$ & $\begin{array}{l}\text { Self analysis tool } \\
\text { intended to reveal } \\
\text { teacher strengths and } \\
\text { weaknesses in techn- } \\
\text { ology proficiency and } \\
\text { integration } \\
\text { Identifies areas where } \\
\text { further training is } \\
\text { indicated }\end{array}$ & $\begin{array}{l}\text { Aligned with NETS; probes } \\
16 \text { uses of technology to } \\
\text { profile how extensively } \\
\text { technology is integrated } \\
\text { into classrooms }\end{array}$ & I \\
\hline $\begin{array}{l}\text { NCRTEC } \\
\text { www.ncrtec.org/ } \\
\text { capacity/profile/ } \\
\text { profile.htm }\end{array}$ & $\begin{array}{l}\text { Intended for teachers } \\
\text { to determine how } \\
\text { effectively they } \\
\text { engage students in } \\
\text { learning through the } \\
\text { use of technology; } \\
\text { and how well their } \\
\text { technology resources } \\
\text { support their practice }\end{array}$ & $\begin{array}{l}\text { Explores two aspects of } \\
\text { technology integration: } \\
\text { Indicators of Engaged } \\
\text { Learning, which } \\
\text { exclusively surveys } \\
\text { teaching practices; and } \\
\text { Indicators of High } \\
\text { Performance Technology, } \\
\text { which examines technology } \\
\text { resources }\end{array}$ & $\begin{array}{l}\text { I*, II, III*, IV, }^{*} \text { V, VI, VII } \\
\text { * only } \\
\text { moderate } \\
\text { attention } \\
\text { given to } \\
\text { these } \\
\text { standards }\end{array}$ \\
\hline
\end{tabular}

While each of the instruments address ISTE Standards I to VII in some part (see Table 2), only NRCTEC and TAGLIT addressed all seven ISTE standards. NRCTEC placed only minor focus on Standards I (Technology Operations and Concepts) and III (Teaching, Learning, and the Curriculum). Standard II, Planning and Designing Learning Environments and Experiences, was addressed by addressed by every survey except CTAP2 and the Mankato Scale.

Because the authors found it was difficult to discriminate the focus and purposes of each of the tests, they decided to restructure information about test content as a chart (see Figure 1). Figure 1 is divided into four quadrants or domains: Basic Skills and Digital Processes, Technology Issues, Pedagogical Methods and Approaches, and "Stuff". Items on the left side of the chart are focused on technological knowledge and skills as well as 
Table 2: Correspondence between technology assessment tools and ISTE Standards I - VII (Addressing technology in the classroom)

\begin{tabular}{|c|c|c|c|c|c|c|}
\hline Instruments & SEIR $^{* T E C}{ }^{*}$ & TAGLIT & EnGauge & $\mathrm{CTAP}^{2}$ & Mankato & NCRTEC \\
\hline $\begin{array}{l}\text { St I Technology } \\
\text { operations and } \\
\text { concepts }\end{array}$ & $X$ & & & $X$ & $\mathrm{X}$ & $\begin{array}{l}\text { Minor } \\
\text { focus of } \\
\text { survey }\end{array}$ \\
\hline $\begin{array}{l}\text { St II Planning and } \\
\text { designing learning } \\
\text { environments and } \\
\text { experiences }\end{array}$ & $X$ & $X$ & $\mathrm{X}$ & & & $\mathrm{X}$ \\
\hline $\begin{array}{l}\text { St III Teaching, } \\
\text { learning, and the } \\
\text { curriculum }\end{array}$ & $X$ & $X$ & & $X$ & & $\begin{array}{l}\text { Moderate } \\
\text { focus of } \\
\text { survey }\end{array}$ \\
\hline $\begin{array}{l}\text { St IV Assessment and } \\
\text { evaluation }\end{array}$ & $X$ & $X$ & & & & $\mathrm{X}$ \\
\hline $\begin{array}{l}\text { St V Productivity and } \\
\text { professional practice }\end{array}$ & & $X$ & & & & $X$ \\
\hline $\begin{array}{l}\text { St VI Social, ethical, } \\
\text { legal, and human } \\
\text { issues }\end{array}$ & & $X$ & $X$ & & $X$ & $X$ \\
\hline $\begin{array}{l}\text { St VII Procedures, } \\
\text { policies, planning, } \\
\text { and budgeting for } \\
\text { technology } \\
\text { environments }\end{array}$ & & $X$ & $X$ & & & $X$ \\
\hline $\begin{array}{l}\text { St VIII Leadership } \\
\text { and vision }\end{array}$ & & $X$ & & & & $\begin{array}{l}\text { Minor } \\
\text { focus of } \\
\text { survey }\end{array}$ \\
\hline
\end{tabular}

* Items are from SEIR*TEC LoFTI (Looking for Technology Integration)

Observation Survey, not self-report SEIR*TEC Progress Gauge

the practical issues encountered in creating a technology infused learning environment. Items on the right side of the chart deal with pedagogy and two areas that target the human element, loosely termed "Stuff," a term borrowed from TAGLIT. It is easy to see that the predominant focus of CTAP2 and the Mankato Scale is technology - basic skills and resources. $S E I{ }^{*} T E C$ zeros in on pedagogy and teaching application. EnGauge, NRCTEC and TAGLIT all appear to maintain a balance between technology and pedagogy, but of those three, only TAGLIT takes stock of the teacher's discreet skill set for technology application. The Mankato Scale differs from CTAP2 in that it surveys 16 specific uses of technology in comparison to CTAP2's seven. The Mankato Scale was also one of the three surveys to address ISTE Standard VI - Social, Ethical, Legal, and Human Issues in educational technology use.

The assessment of technology integration may occur squarely within a framework of pedagogical processes, or it may emphasise skills that 


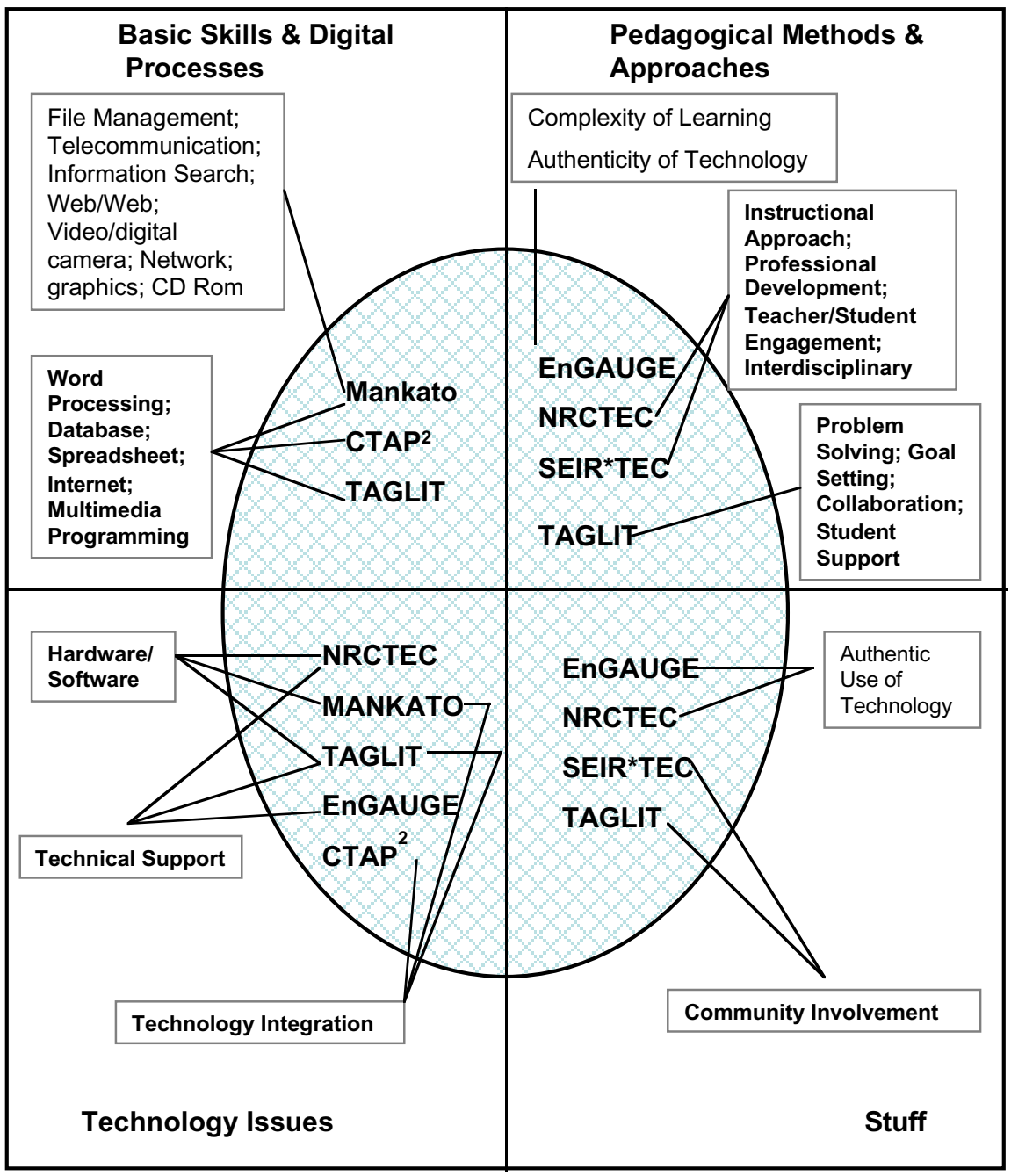

Figure 1: Chart of test content

advance the use of technology in the classroom. These are very different perspectives on technology integration; but are nonetheless complementary aspects of assessment. This study examined tools whose content overlapped, but whose perspectives on the place of technology in the classroom likewise differed. The Mankato Scale and CTAP emphasise instrumentality, i.e. levels of skill and the extent to which skill is embedded in day to day instruction. NCRTEC and enGauge appear to employ a 
definition of technology integration that situates technology in real contexts of instruction. TAGLIT employs both a focus on instrumentality and skill and upon situated pedagogy. The tools may complement one another; but the possibility of conducting systematic studies of statistical validity seems less feasible once one realises the operational principles that match content to construct for each tool also limit what each tool can be expected to measure. Thus the Mankato Scale would be the wrong test to use if one defines integration in terms of pedagogical process; and similarly en Gauge cannot fairly be used to measure a broadly defined domain of skills.

\section{Conclusions}

Two questions emerge as important from this analysis. Have there been systematic efforts to demonstrate that assessments of technology integration with instructional practice are valid? What kinds of assessment will be needed to judge a teacher's competence in the ever expanding domain of technology integration, if one is to accurately reflect the broad spectrum of skills that teachers are expected to use and in fact do use?

For assessment to be valid one must assume that assessment tools have been field tested using populations that are good proxies for the subgroups in any population that eventually will be evaluated. Assessment is also expected to sample an adequate range of behaviours and abilities for the purpose of making judgments and then decisions that are fair and meaningful. That may not be the case when using assessments of technology integration that are available today. These tools are unlikely to be based upon the responses of adequate samples. They are all different in terms of their content, providing only modest overlap of content, and thus there is no way to demonstrate many of the forms of statistical validity that depend upon criterion related correlations. Individually these tools sample a very limited collection of teacher knowledge and skill. Against a backdrop of rapidly expanding expectations and rapid change, the tests are probably unable to capture what teachers need to do, and more importantly what they actually are doing.

To address the inadequacy of many standardised assessments that are in vogue today, multiple forms of assessment may be needed as part of a systematic study of teacher competence. These approaches may also need to go beyond the images of computers where children are engaged in drill, practice and reinforcement. They also need to go beyond the view that a single tool or assessment system will be sufficient.

More measurement research is needed that promotes technically sound assessment of technology integration. The development of observational 
tools is called for because observational methods are more able to study the skills needed by teachers to accomplish integration. Assessment measures will increasingly need to anticipate the near horizon of technological change. Rather than adopting a singular focus on technology and its tools, assessment may also benefit from content that explores a teacher's understanding of instructional designs that incorporate technology in pedagogically sound ways. More studies are needed to determine how various subgroups of educators understand, define and apply the construct termed the integration of technology in classroom practice.

Anastasi and Urbino (1978) stressed that construct validity cannot be demonstrated without also testing one's theoretical definition of technology integration. Future studies of technology assessment should therefore tie test scores to other variables that are logically associated with the assessment of technology integration and differences in instructional behaviors. Technology integration arguably should be correlated with independent measures that assess other dimensions of use, including:

1. Access to resources and support;

2. Expertise in using technology;

3. Having networks of colleagues who provide mentoring and modeling;

4. The availability of technology rich learning spaces

5. Understanding the pedagogical reasons for integrating technology;

6. Participation in curriculum development and instructional design;

7. Positive perceptions of technology and its applications to instruction;

8. Professional development and training.

This perspective on the assessment of technology integration with classroom instruction was inspired by Messick's notion of consequential validity. It is logical to ask whether assessments are robust enough to make judgments about teachers that are useful, meaningful and fair. Frequently technology itself changes course, causing the assessment of competence take on a completely new set of challenges, making the growth of professional knowledge and skills follow a completely new path which is not linear and in which change cannot be assumed to occur incrementally. Because of these challenges, the validity and value of technology integration assessment can be demonstrated only by a stepwise strategy that takes place over time.

\section{References}

CTAP Online iAssessment E Technology Use Survey. [viewed 21 Apr 2005, verified 28 Sep 2006] http://www.scusd.edu/education_technology/CTAP_online_iassessment.htm

Cattell, R. B. (1978). The scientific use of factor analysis in behavioral and life sciences. New York, NY: Plenum. 
Cook, T. D. \& Campbell, P. T. (1979). Quasi-experimentation: Design and analysis, issues for field settings. Boston, MA: Houghton-Mifflin.

Cronbach, L. (1989). Construct validation after thirty years. In R. L. Linn (Ed), Intelligence: Measurement, theory and public policy (pp. 147-171). Urbana: University of Illinois Press.

en Gauge. A framework for effective technology use. [viewed 21 Apr 2005, verified 28 Sep 2006] http:/ / www.ncrel.org/engauge/

Fink, A. (Ed) (1995). The survey handbook. Thousand Oaks, CA: Sage.

Forster, P. A., Dawson, V. M. \& Reid, D. (2005). Measuring preparedness to teach with ICT. Australasian Journal of Educational Technology, 21(1), 1-18. http:/ / www.ascilite.org.au/ajet/ajet21/forster.html

Goldstein, G. \& Hersen, M. (Eds) (1984). Handbook of Psychological Assessment. New York: Pergamon Press.

Gorsuch, R. L. (1983). Factor analysis (2nd ed.). Hillsdale, NJ: Lawrence Erlbaum.

Guttman, L. (1950). The basis for scalogram analysis. In Stouffer et al. (Eds), Measurement \& Prediction, The American Soldier, Vol. 4. New York: Wiley.

International Society for Technology in Education. http:/ / www.iste.org/

Linacre, J. M. (2000). Guttman coefficients and Rasch data. Rasch Measurement Transactions, 14(2), 746-747. [verified 7 Oct 2006] http:/ / www.rasch.org/rmt/rmt142e.htm

Johnson, D. (1998). The indispensable teachers guide to computer skills: A staff development guide. Worthington, Ohio: Linworth Publishing, Inc.

Kerlinger, F. N. (1979) Behavioral research: A conceptual approach. New York: Holt, Rinehart \& Winston.

Kinzer, C. K. \& McKenna, M. C. (1999). Using technology in your classroom literacy program: Current and future possibilities. Paper presented at the 44th Annual Convention of the International Reading Association, San Diego, CA.

Leamnson, R. (2001). Does technology present a new way of learning? Educational Technology \& Society, 4(1), 75-79. [verified 7 Oct 2006] http:/ / www.ifets.info/journals /4_1/leamnson.html

McKenzie, J. (1994). From technology refusal to technology acceptance: A reprise. From Now On: The Educational Technology Journal, 4(9), 1-12. [viewed 28 Oct 2004, verified 7 Oct 2006] http://www.fno.org/may94fno.html

McKenzie, J. (1998). Assessing professional growth in skill and use. Staffdevelop.org. [verified 7 Oct 2006] http:/ / staffdevelop.org/gauge.html

Messick, S. (1993). Foundations of validity: Meaning and consequences in psychological assessment. Educational Testing Service. Princeton, New Jersey.

Moersch, C. (1999). Assessing current technology use in the classroom: A key to efficient staff development and technology planning. Leading and Learning with Technology, 26(8), 40-49. [verified 7 Oct 2006] http:/ / www.learningquest.com/software/AssessTechUsemay99.pdf

Moersch, C. (2002). Measures of success: Six instruments to assess teacher's use of technology. Leading and Learning with Technology, 30(3). 10-25. [verified 7 Oct 2006] http://www.learning-quest.com/software/MeasurersOfSuccessNov02.pdf 
Moersch, C. (2004). Validity and reliability. [viewed 5 Jan 2005, verified 7 Oct 2006] http:/ / www.loticonnection.com/validandreliable.html

National Educational Technology Standards. NETS for Teachers. [viewed 1 Aug 2006, verified 7 Oct 2006] http:/ / cnets.iste.org/sitemap.html\#teachers

Nunnally, J. C. (1978). Psychometric theory (2nd ed). New York: McGraw-Hill.

Oliver, R. \& Omari, A. (1999). Using online technologies to support problem based learning: Learners' responses and perceptions. Australian Journal of Educational Technology, 15(1), 58-79. http://www.ascilite.org.au/ajet/ajet15/oliver.html

Pope, M., Hare, D., \& Howard, E. (2002). Technology integration: Closing the gap between what preservice teachers are taught to do and what they can do. Journal of Technology and Teacher Education, 10(2), 191-203.

Recesso, A. M. (2002). The intersection of parallel reform efforts through professional development: Connecting learning standards and technology. TechTrends, 46(3), 39-42.

Robertson, M., Fluck, A., Webb, I. \& Loechel, B. (2004). Australasian Journal of Educational Technology, 20 (3), 351-370. http://www.ascilite.org.au/ajet/ajet20/robertson.html

Ryan, T. (2003). Aligning course activities with ISTE-NETS standards. [viewed 29 Nov 2004, verified 7 Oct 2006] http:/ / pages.towson.edu/pryan/research/paper

Russ-Eft, D. F. (1980). Validity and reliability in survey research. American Institutes for Research in the Behavioral Sciences August, 227, 151.

SEIR*TEC (2000). Technology Integration Progress Gauge Profiler Version. [verified 7 Oct 2006] http:/ / www.seirtec.org/publications /ProgressGauge2000.PDF

TAGLIT. [viewed 21 Apr 2005, verified 7 Oct 2006] http:/ /www.taglit.org/

Thompson, B. \& Daniel, L. G. (1996). Factor analysis evidence for the construct validity of scores: A historical overview and some guidelines. Educational and Psychological Measurement, 56(2), 197-208.

Trochim, W. M. (2002). Reliability and validity. [viewed 7 Jan 2005, verified 7 Oct 2006] http:/ / www.socialresearchmethods.net/kb/rel\&val.htm

Wepner, S. B. \& Tao, L. (2002). From master teacher to master novice: Shifting responsibilities in technology-infused classrooms. The Reading Teacher, 55(7), 212.

Wilson, M. (Ed) (1992-1994) Objective measurement: Theory into practice (Vols. 1-2). Norwood, NJ: Ablex.

Kathleen A. Bowes, EdD and Antonia A. D'Onofrio, $P h D$

Center for Education, Widener University

1 University Place, Chester, Pennsylvania 19013, USA

Email: Kathleen.A.Bowes@widener.edu, Antonia.A.D'Onofrio@widener.edu

Elaine Marker, School of Education, Rowan University, 201 Mullica Hill

Road, Glassboro, New Jersey 08028, USA. Email: marker@rowan.edu 